\title{
COMPARING THE EFFECT OF TWO COATING METHODS OF Tetragonula laeviceps PROPOLIS WATER EXTRACTION ON PHYSICAL QUALITY AND SHELF LIFE OF EGGS KEPT IN ROOM TEMPERATURE
}

\author{
KINASIH, I. , JULITA, U., SURYANI, Y., CAHYANTO, T., KHOIRUNNISA, E.M. \\ and PUTRA, R.E. \\ Department of Biology, Faculty of Sciences and Technology, \\ Universitas Islam Negeri Sunan Gunung Djati Bandung, Indonesia \\ Agricultural Engineering Study Program, School of Life Sciences and Technology, \\ Insitut Teknologi Bandung, Indonesia \\ *E-mail: idakinasih@uinsgd.ac.id
}

Accepted 26 April 2020, Published online 6 July 2020

\begin{abstract}
Studies show that in the tropical region, like Indonesia, eggs have a low shelf life, ranging from 10 to 14 days when kept at room temperature. The application of natural coating material, such as propolis, could improve the shelf life of eggs. However, due to the high cost of the material, it is necessary to find more efficient application methods. In this study, propolis extraction using aquadest as solvent was applied, by brushing and spraying, to 180 fresh eggs of local chicken (Gallus sp.) aged 24 hours with another 180 eggs, without propolis coating, designed as control. All eggs were kept in room temperature for 35 days and changes on the albumen index, yolk index, and height of air sacs were measured every 7 days. This study showed that the different application methods did not significantly affect the value of the albumen index and yolk index for each observation time, but haugh unit and height of the air cell. However, the result indicated that the application of propolis by spraying maintained egg quality for a longer time than brushing and the average shelf life of eggs sold at the local market.
\end{abstract}

Key words: Chicken eggs, coating, propolis, shelf life

\section{INTRODUCTION}

The chicken egg is a food which has a complete balance of essential nutrients for human (Kinoshita, et al., 2002). Furthermore, it also has a low cost which increased its popularity as food in the lowincome population in Indonesia. However, the nutrition quality of eggs starts to deteriorate immediately after its laid and during storage. Rate of deterioration is affected by strain and age of hen, storage time and conditions (Stadelman, 1995). The deterioration of egg is due to the change of the internal part of the egg as the embryo is developed. Even though eggshell protects the internal part of the egg, it is porous and breathable; thus allowing movement of moisture and carbon dioxide through the shell which affects the life of the embryo inside the egg (Wong et al., 1996). This may cause

\footnotetext{
* To whom correspondence should be addressed.
}

physical and chemical changes in albumen and yolk, reducing the weight and quality of egg for consumers (Copur et al., 2008). Studies showed that preventing movement of moisture and carbon dioxide reduces the deterioration rate of the interior part of the egg (Bhale et al., 2003). Furthermore, combining it with sanitizing could significantly increase the shelf-life of the eggs (Park et al., 2003). Usually prevention of water and carbon dioxide movement is conducted by the application of coating material on eggshells while sanitizing by disinfectant. Thus, the application of coating material that sanitizes egg while reducing the movement of water and carbon dioxide would increase the effectiveness of egg preservation procedure. One of the potential coating materials which is considered safe for humans is propolis.

Propolis is a mixture of beeswax and results from plant buds, leaves, and exudates (Ghisalberti, 1979) which is collected by worker honeybees (Apis 
melifera), in temperate regions, and Trigona sp., in tropical regions (Greenaway et al., 1990). Among natural products, this substance has received more attention due to its strong anti-bacterial, anti-fungal and anti-viral properties against a wide range of pathogenic microorganisms, and has been used in various agricultural products as a coating material to reduce a post-harvest loss (Burdock, 1998). Our previous study showed that $2.5 \%$ of propolis extract was the best concentration for coating. However, since the high cost of production, it is necessary to develop an efficient alternative coating method to reduce material loss (Kinasih et al., 2015). Thus, in this study, we tested the effect of spraying and brushing as coating methods of propolis to the preservation of egg quality. Furthermore, due to the reluctance of most Indonesia people to apply ethanol to food material and the high cost of ethanol products, in this study, we applied propolis water extraction as the main source for coating.

\section{MATERIALS AND METHODS}

\section{Propolis extraction}

Raw propolis extract was taken from the beehives of Trigona sp. at Dago area in Bandung, West Java. The propolis extract was prepared according to Pujirahayu et al. (2015) with modification. Raw propolis was immersed in $70 \%$ ethanol with ratio $1: 1(\mathrm{w} / \mathrm{w})$, kept inside a dark bottle, and shaken on a rotator for 7 days. Ethanol Extract Propolis (EEP) was obtained by filtering the solution with filter paper. Before application, Aquadest Extract Propolis (AEP) was produced by mixing $200 \mathrm{ml}$ of EEP and $200 \mathrm{ml} 20 \mathrm{mM}$ phosphate buffer filter in a 500-ml flask and kept on a magnetic stirrer for $20 \mathrm{~min}$ at $20^{\circ} \mathrm{C}$. The mixture was centrifuged at $7000 \mathrm{rpm}$ for $15 \mathrm{~min}$ and the supernatant was collected (Najafi et al., 2007). AEP was then diluted with aqua dest to produce $2.5 \%$ propolis solution.

\section{Propolis application}

About 540 brown and smooth eggs (no crack) were used in this study. The eggs were sorted and weighed (between 40-60 g) to reduce the variation of eggs. Eggs were applied with $2.5 \%$ propolis extract by brushing and spraying. Eggs were then kept at room temperature for 35 days.

The degradation of the albumen index (AI), yolk index (YI), the height of the air cell, and Haugh Unit (HU) were measured every 7 days. For sampling, each egg was broken on a flat surface, using a transparent glass plate, where the height of the albumen, diameter of the albumen, height of yolk and diameter of the yolk was measured by a digital caliper. Albumen index (AI) was calculated using the formula:

$$
\mathrm{AI}=\left[\frac{\mathrm{H}}{0.5(\mathrm{D} 1+\mathrm{D} 2)}\right] \times 100
$$

where:

$\mathrm{H}=$ Albumen height ( $\mathrm{mm}$ )

$\mathrm{D} 1=$ outer diameter of thick albumen $(\mathrm{mm})$

D2 $=$ shortest diameter of thick albumen ( $\mathrm{mm}$ )

Yolk index (YI) was calculated using the formula:

$$
\mathrm{YI}=\frac{\mathrm{h}}{0.5(\mathrm{~d} 1+\mathrm{d} 2)}
$$

where:

$\mathrm{h}=$ Yolk height $(\mathrm{mm})$

$\mathrm{d} 1=$ outer diameter of yolk $(\mathrm{mm})$

$\mathrm{d} 2=$ shortest diameter of yolk $(\mathrm{mm})$

Haugh unit were calculated using the HU formula (Raji et al., 2009):

$$
\mathrm{HU}=100 \log \left(\mathrm{H}+7,5-1,7 \mathrm{~W}^{0,37}\right)
$$

where $\mathrm{H}=$ height of albumen (mm); $\mathrm{W}=$ egg weight (g).

\section{Data analysis}

The data was subjected to Duncan's multivariate Test to detect differences on each parameter among all treatments. The generalized linear model was produced to find the pattern of changes in the albumen index, yolk index, height of air cell, and Haught index with time. The data collected was analyzed using SPSS ver. 22 and PAST version 3.26.

\section{RESULTS AND DISCUSSION}

In general, all eggs showed lower albumen and yolk index than premium eggs which may be due to lowquality nutrition received during egg production. Albumen index of all eggs of all groups decreased with increasing storage period which agrees with the result of Tilki and Saatci (2004) and Copur et al. (2008). The effect of the application of propolis as egg coating did not significantly influence the change of albumen and yolk condition $(p>0.05)$ (Fig. 1). In the case of the albumen index, we found slower albumen index reduction in the control group compared to both coated groups. There were no differences in the decreasing level of albumen quality between both coated groups although the level of reduction of eggs coated by spraying method was slightly less than the brushing method for a long time (Figure 1). Both coating methods 
were only able to maintain the albumen quality up to 15 days. On the other hand, the application of PWE by spraying was more likely to maintain the quality of yolk for a long time compared to the control group and brushing group (Figure 1). This study also showed that the application of AEP as a coating material for eggs could maintain the albumen and yolk condition up to 21 days as compared to the control group and brushing group in which the quality of good yolk was only up to 15 days.

The results were contradictory to other studies that egg coating prevented both albumen and yolk deterioration (Park et al., 2003; Copur et al., 2008). It seems that chemical composition of AEP, which was highly different from alcoholic extracts (Park \& Ikegaki, 1998; Mello et al., 2010), was unable to protect albumen and yolk deterioration, that is mostly caused by increase in $\mathrm{pH}$ of inner egg environment (Walsh et al., 1995; Samli et al., 2005).

Figure 2 shows that air cell size increased with increased storage time. Increasing the height of the air cell is caused by the development of chick. The water vaporised through eggshell replaced by a mass of oxygen diffusing into the egg is balanced by carbon dioxide leaving the egg (Stadelman, 1995). Air that replaces water vapor accumulates in the air cell caused the increasing height of air cells (Ar, 1991). The application of propolis by brushing and spraying significantly maintained the quality of egg based on the height of the air cell $(\mathrm{p}<0.05)$ (Figure 2). Results also showed that both methods did not show significant difference, which indicated both methods could provide good coating results of egg although the regression model showed a lower slope of the brushing group which predicted slightly lower height of air cell in a long time.

Increasing storage time reduced the HU of the eggs, which is consistent with other studies (Samli et al., 2005; Keener et al., 2006; Raji et al., 2009; Singh et al., 2014). There are differences in the initial HU of the eggs used in this study even though all eggs were harvested at the same time from the same age group of chicken, from a selected chicken farm which indicated the variation of quality of the eggs produced by local farms. This study showed that both applications significantly showed a higher rate of $\mathrm{HU}$ reduction in the control group (Figure 3 ). The results were not similar to studies showing the positive impact of coated eggs on HU (Homler \& Stadelaman, 1963; Tanabe, 1978; Park et al., 2003). During storage, carbon dioxide is lost through the pores of the eggshell (Sharp \& Powel, 1931). This condition increases the $\mathrm{pH}$ of the albumen (Chukwuka et al., 2011). Increasing $\mathrm{pH}$ will cause some denaturation of proteins and a decrease in HU (Stadelman, 1995). Besides storage time, other factors that can negatively affect HU are hen genetics, hen age, and disease (Toussant \& Latshaw, 1999). It seems that the application of propolis water extraction improved the rate of gas exchange between the inner and outer part of the egg. Further studies are required to test this hypothesis.

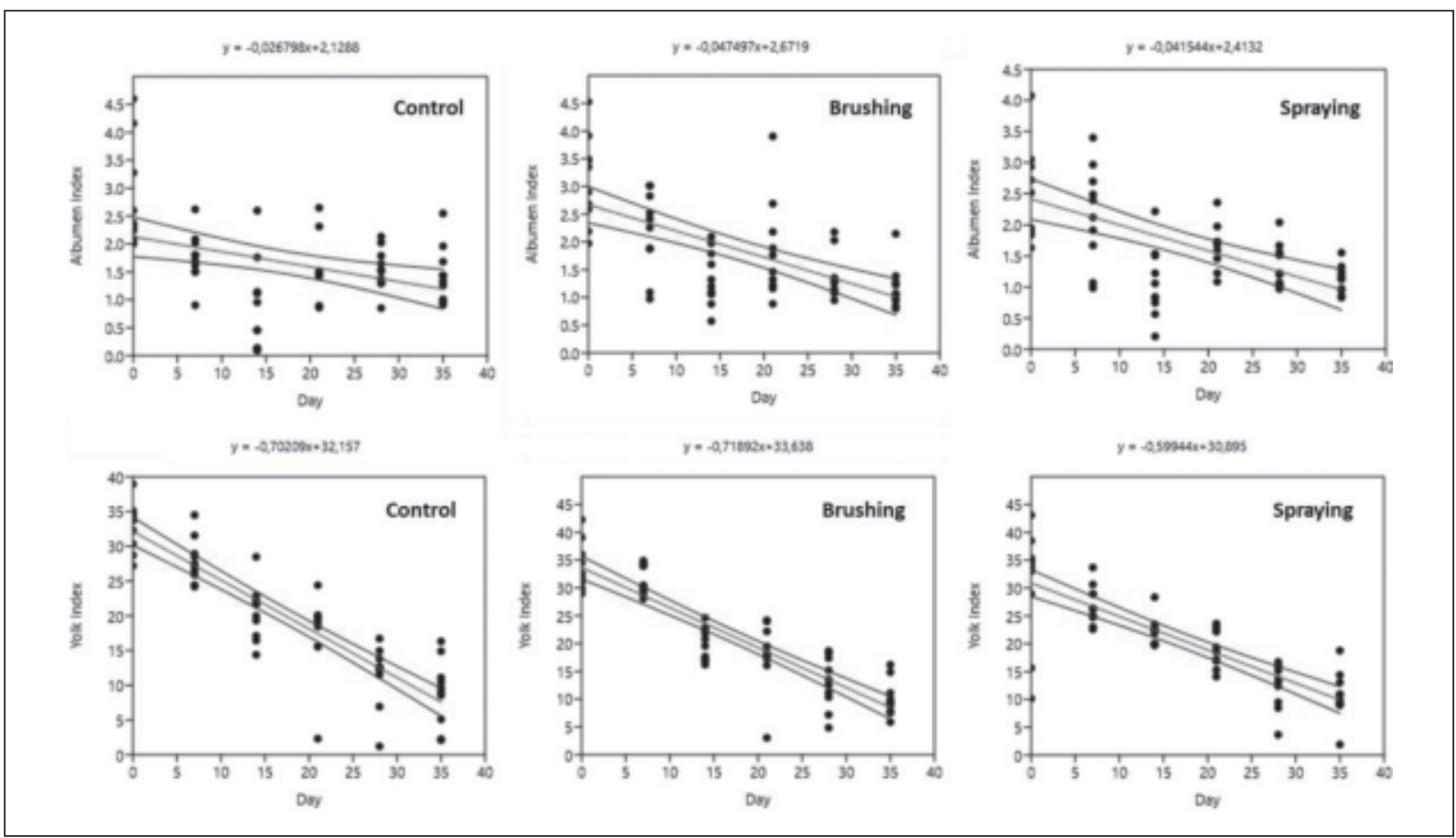

Fig. 1. Changes of albumen index (above) and yolk index (below) for eggs applied with propolis extract at different methods. 


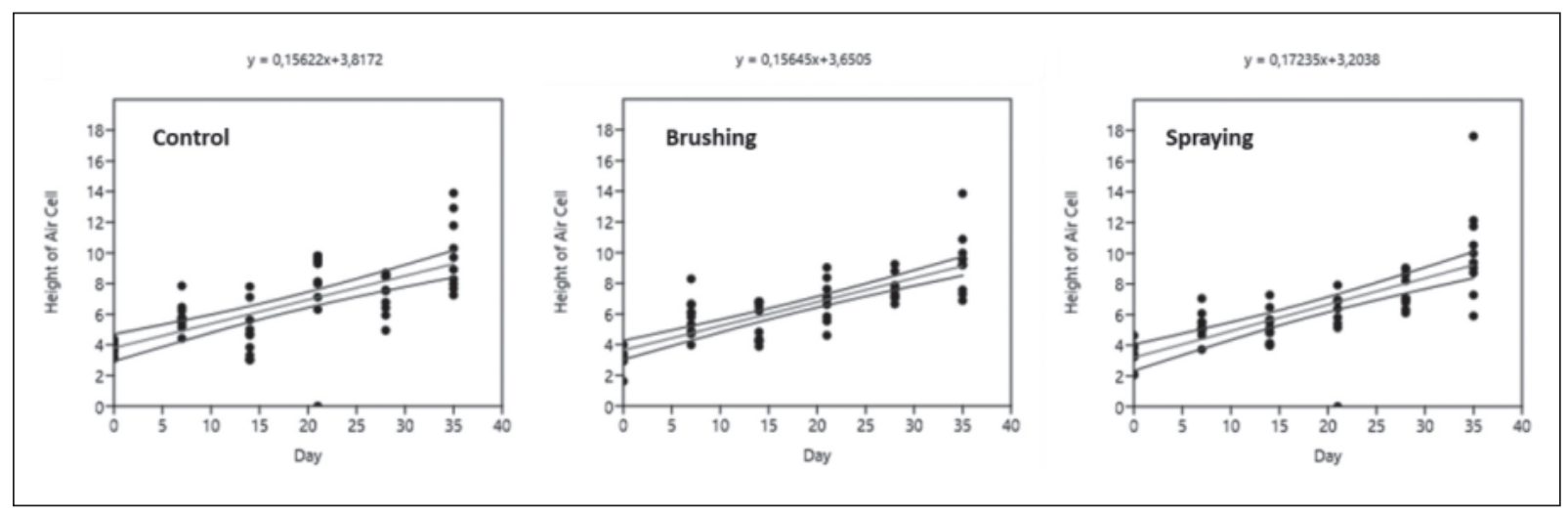

Fig. 2. Changes of the height of the air cell for eggs applied with propolis extract at different methods.

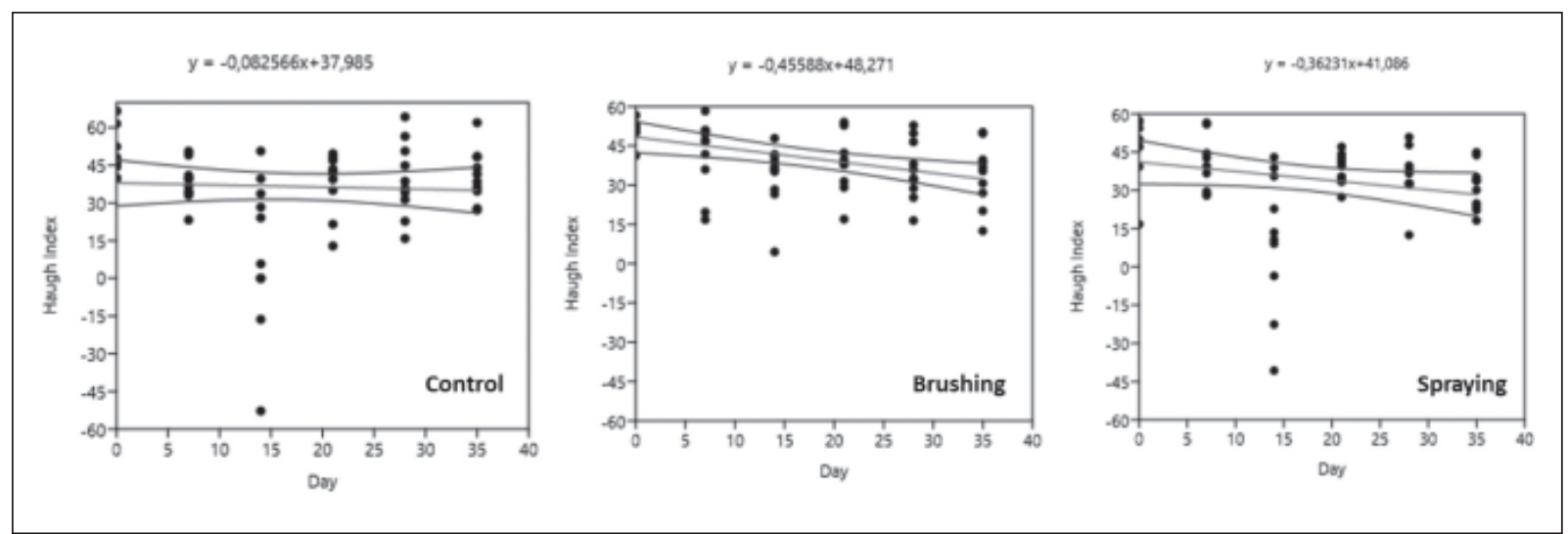

Fig. 3. Changes of Haugh Unit for eggs without propolis coating and with propolis coating by brushing and spraying.

Similar to the result in air cell, the effect did not significantly vary between both methods during the study period. However, based on the regression linear model of data, we found a lower slope of the spraying group which may predict that in a long time spraying group would have higher HU than the brushing group.

The changes in the albumen index, yolk index, the height of air cell, and Haugh unit values did not show the positive impact of propolis water extraction coating to maintain the best quality of eggs. Between both coating methods, eggs sprayingcoated by propolis water extraction was slightly more useful than brushing-coated propolis in the longer storage time.

\section{ACKNOWLEDGMENTS}

This study was funded by DIPA-BOPTAN UIN Sunan Gunung Djati Bandung 2016 granted to the first author and Program Penelitian Kolaborasi Indonesia 2019 granted to the last author.

\section{REFERENCES}

Ar, A. 1991. Egg water movements during incubation. In: Avian Incubation. S.G. Tullett (Ed.). Butterworth-Heinemann, London. pp. 157-173.

Bhale, S., No, H.K., Prinyawiwatkul, W., Farr, A.J., Nadarajah, K. \& Meyers, S.P. 2003. Chitosan coating improves shelf life of eggs. Journal of Food Science, 68: 2378-2383.

Burdock, G.A. 1998. Review of the biological properties and toxicology of bee propolis (propolis). Food and Chemical Toxicology, 36(4): 347-63.

Chukwuka, O.K., Okoli, I.C., Okeudo, N.J., Udedibie, A.B.I., Ogbuewu, I.P., Aladi, N.O., Iheshiulor, O.O.M. \& Omded, A.A. 2011. Egg quality defects in poultry management and food safety. Asian Journal of Agricultural Research, 5: 1-16.

Copur, G., Camci, O., Sahinler, N. \& Gul, A. 2008. The effect of propolis egg shell coatings on interior egg quality. Archiv fur Geflugelkunde, 72: $35-40$. 
Ghisalberti, E.L. 1979. Propolis: A review. Bee World, 60(2): 59-84.

Greenaway, W., Scaybrook, T. \& Whatley, F.R. 1990. The composition and plant origins of propolis: A report of work at Oxford. Bee World, 71(3): 107-18.

Homler, B.E. \& Stadelman, W.J. 1963. The effect of oiling before and after cleaning in maintaining the albumen condition of shell eggs. Poultry Science, 41: 190-194.

Keener, K.M., McAvoy, K.C., Foegeding, J.B., Curtis, P.A., Anderson, K.E., Osborne, J.A. 2006. Effect of testing temperature on internal egg quality measurements. Poultry Science, 85: 550555.

Kinasih, I, Putra, R.E., Suryani, Y., Purwati, F.E. \& Rizkiandi, T. 2015. Effect of propilis coating on the quality of eggs: microbial contamination and haugh unit. Proc. The First International Conference on Life Science and Biotechnology and Conservation of Biodiversity (Jember) Indonesia, 28-29 September 2015.

Kinoshita, K., Okamoto, S., Shimogiri, T., Kawabe, K., Nishida, Kakizawa, T.R., Yamamoto, Y. \& Maeda, Y. 2002. Gene constitution of egg white proteins of native chicken in asian countries. Asian-Australasian Journal of Animal Sciences, 15: 157-165.

Mello, B.C.B.S., Petrus, J.C.C. \& Hubinger, M.D. 2010. Concentration of flavonoids and phenolic compounds in aqueous and ethanolic propolis extracts through nanofiltration. Journal of Food Engineering, 96(4): 533-539.

Najafi, M.F., Vahedy, F., Seyyedin, M., Jomehzadeh, H.R. \& Bozary, K. 2007. Effect of the water extracts of propolis on stimulation and inhibition of different cells. Cytotechnology, 54: 49-56.

Park, Y.K. \& Ikegaki, M. 1998. Preparation of water and ethanolic extracts of propolis and evaluation of the preparations. Bioscience, Biotechnology and Biochemistry, 62(11): 22302232.

Park, Y.S., Yoo, I.J., Jeon, K.H., Kim, H.K., Chang, E.J. \& Oh, H.I. 2003. Effects of various eggshell treatments on the egg quality during storage. Asian-Australasian Journal of Animal Sciences, 16: 1224-29.
Pujirahayu, N., Ritonga, H., Agustina, S. \& Uslinawaty, Z. 2015. Antibacterial activity of oil extract of trigona propolis. International Journal of Pharmacy and Pharmaceutical Science, 7(6): 419-422.

Raji, A.O., Aliyu, J., Igwebuike, J.U. \& Chiroma, S. 2009. Effect of storage methods and time on egg quality traits of laying hens in a hot dry climate. Journal of Agricultural and Biological Science, 4(4): 1-7.

Samli, H.E., Agma, A. \& Senkoylu, N. 2005. Effects of storage time and temperature on egg quality in old laying hens Journal of Applied Poultry Research, 14: 548-53.

Sharp, P.F. \& Powel, C.K. 1931. Increase in the $\mathrm{pH}$ of the white and yolk of hen's eggs. Journal of Industrial and Engineering Chemistry, 23: 19699.

Singh, J., Sharma, H.K., Premi, M. \& Kumari, K. 2014. Effect of storage conditions of eggs on rheological properties of liquid whole egg. Journal Food Science and Technology, 51(3): 543-50.

Stadelman, W.J. 1995. The preservation of quality in shell eggs. In: Egg Science and Technology. 4th ed. W.J. Stadelman and O.J. Cotterill (Eds.). Food Products Press, New York, NY. pp. 67-79.

Tanabe, H. 1978. Survey of the methods for long term storage of poultry eggs. 13. The effect of washing, oiling and holding on interior quality of the chicken eggs. Japan Poultry Science, 15: 55-63.

Tilki, M. \& Saatci, M. 2004. Effect of storage time on external and internal characteristics in partridge (Alectoris graeca) eggs. Revue de Médecine Vétérinaire, 155(11): 561-564.

Toussant, M.J. \& Latshaw, J.D. 1999. Ovomucin content and composition in chicken eggs with different interior quality. Journal of the Science of Food and Agriculture, 79: 1666-70.

Walsh, T.J., Rizk, R.E. \& Brake, J. 1995. Effects of temperature and carbon dioxide on albumen characteristics, weight loss, and early embryonic mortality of long stored hatching eggs. Poultry Science, 74: 1403-1410.

Wong, Y.C., Herald, T.J. \& Hachmseister, K.A. 1996. Evaluation of mechanical and barrier properties of protein coating on shell eggs. Poultry Science, 75: 417-422. 
